\title{
Afrobits: An interactive installation of African music and the Trans-Atlantic slave trade
}

\author{
Javier Pereda \\ Liverpool John Moores University \\ Liverpool, UK \\ j.pereda@limu.ac.uk \\ Lois South \\ University College London \\ London, UK \\ loissouth2@gmail.com
}

\author{
Patricia A. Murrieta-Flores \\ Lancaster University \\ Lancaster, UK \\ p.murrieta@lancaster.ac.uk
}

\author{
Nicholas Radburn \\ Lancaster University \\ Lancaster, UK \\ n.radburn@lancaster.ac.uk \\ Christian Monaghan \\ EatenAlive \\ Warrington, UK \\ contacteatenalive@gmail.com
}

\begin{abstract}
This paper introduces Afrobits, an interactive installation about African music and the TransAtlantic slave trade. Its main aim is to bring to light invisible stories hidden behind geographic epistemologies. The installation highlights the contribution that African cultures had on the tangible and intangible cultural heritage of the world, such as popular music. Although it covers diverse countries, we focused on the Americas, placing emphasis on Latin-America as the biopolitical space that enabled the integration of native cultures with African peoples. As this project involved web scientists, graphic designers, historians, digital humanists and artists, we also discuss the benefits of interdisciplinary research; contributions from University researchers for the development of storytelling projects for the Cultural Heritage sector; and the implementation of complex technologies and research methods.
\end{abstract}

Interaction design. Digital humanities. History. Cultural heritage. Museum studies.

\section{INTRODUCTION}

Afrobits is an interactive installation that enables audiences to explore a new narrative of the TransAtlantic Slave Trade. It presents the tangible and intangible contribution through sound, music, instruments and stories of people enslaved during the Trans-Atlantic Slave Trade. The installation is a wooden cone structure with attached conductive sensors that are connected to a micro-controller, linked to a sound system. The conductive sensors detect the proximity of the user and triggers a specific sound file through the micro-controller. Afrobits includes 9 points of interaction: Liverpool, Africa, the Middle Passage, Barbados, Cuba, Brazil, Jamaica, and the North and South of the United States of America. Each point of interaction contains a small piece of original research reflecting on the place, its music and African influence, as well as a representative soundtrack, iconography and illustrations of local life (see Figure 1). Afrobits thus allows users to engage with Intangible Cultural Heritage through physical interaction with a tangible interface.

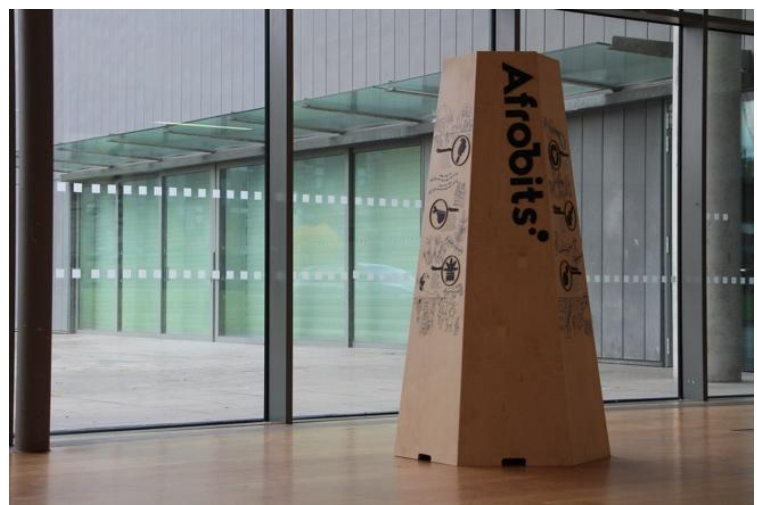

Figure 1: Afrobits Installation

The installation's story begins with Liverpool, the largest slave trading port in the $18^{\text {th }}$ century, which shipped 1.4 million enslaved people to the Americas (Eltis 2018). Despite its deep links to the slave trade, Liverpool's slaving heritage remains a controversial subject embedded with misconceptions and prejudice. Many peopleincluding Liverpudlians-remain ignorant about the 
topic. The Trans-Atlantic Slave Trade has continued to be, until recently, a neglected topic for the vast majority of museums, especially those in countries that directly benefited from the trade (Leffler 2006). Museums were agents of Empire during the eighteenth and nineteenth century, which showcased racialised ideas of colonial 'others' while bolstering national pride for those in the metropole. Wintle argues that collecting material culture, was at the centre of colonial projects in which museums took an active role (Wintle 2013, p.2). Due to Western biopolitical narratives, many museums among other heritage organisations remain agents of Empire. Nevertheless, recent attempts have been made by museums to confront the painful legacy of slavery. As slavery is a process rather than an event (Ennals 2007, pp.181-182), it has been argued that decolonising museums must be a proactive, allencompassing and on-going process (Giblin et al. 2019, p.472). Addressing the challenges and consequences of this became the main objective behind the creation of Liverpool's International Slavery Museum (Fleming 2005). To engage with the legacy of slavery and Liverpool's cultural organizations, we developed Afrobits using Liverpool's street names as a point of entry. Many of these streets are named after Liverpool's largest slave traders, and they consequently stand today as potent reminders of Liverpool's historic links to the trade (Sanderson 1972).

\subsection{Breaking colonialism}

Despite the great efforts from a wide range of heritage organisations, scholars and academics, we still face epistemic colonialism based on (1) geo-political influences, (2) European and Western phenomenology and existentialism (geo-historical), and (3) the convergence of technology and knowledge systems in which current Western, and particularly Anglo-centres of research and education, have produced a 'universal' set of knowledge that is widely accepted (geo-cultural) (Mignolo 2002). According to Zeuske (2012) up to $80 \%$ of the world's research on the history of slavery comes from the USA, 10\% from Brazil, followed by Great Britain (commonly linked to the USA), Germany, France, Portugal, Spain, Italy, and the Baltic States. British involvement in the TransAtlantic slave trade and the ongoing impact is a particularly under researched area, especially when compared to the USA. The British Empire remains a source of national pride. The loss of the Empire has produced a 'postcolonial melancholia' (Gilroy 2005), which spreads uncertainty around racial and national identity narratives.

The paucity of work on Britain's Imperial past highlights the importance of presenting narratives, which confront these ideas. Moreover, there is a particular need to provide accounts bringing to the forefront non-Western and subaltern histories. Therefore, we aim to bring to light the further biopolitical narratives outside the Anglo-centric epistemology, paying special attention to the cultural developments that emerged from the strong relationship between Africans and native Americans (as in the Americas). African and Latin American historiography remains vastly complicated, and commonly in conflict with US and European research, which in many cases rejects, ignores or oversee empiric, community, and native research (Zeuske 2012, p.89). Work compilations in Afro-Latin American forced mobility, AfroColombian, Afro-Andean, multicultural epistemology, coloniality and multicultural integration (Restrepo \& Rojas 2016) has showcased the need for ethno-education and inclusion of 'invisible' cultural groups in the epistemic, cultural and political construction.

\section{AFROBITS PLACES}

This research was carried with an interdisciplinary perspective merging approaches from History, Digital Humanities, Visual Communication Design, and Interaction Design. We began by querying the Slave Voyages Database (Eltis 2018), which reveals that the vast majority of enslaved Africans were disembarked in Latin America and the Caribbean, rather than North America. To produce the 9 interactive points, we further quantified the data from the Triangular Trade-the socioeconomic triangulation that enabled the commerce of enslaved people, commodities (e.g. sugar cane), and the colonial development of industries and economic power. We also produced an animation to further explain the trade, and especially the people involved, both enslaved and enslavers (see Figure 2).

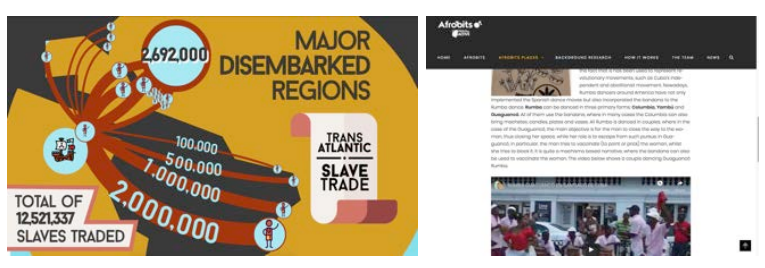

Figure 2: Animation of the Triangular Trade and the Afrobits Website

The installation presents 9 interactive points: Liverpool, Africa, the Middle Passage, Barbados, Cuba, Brazil, Jamaica, and the North and South of the United States of America. Each one of those interactive points has a title (e.g. Cuba), a textual contextualisation of no more than eighty words, it's icon, an illustrative art piece and its soundtrack. These were chosen carefully based on each biopolitical background. We also focused on the reusability of digital collections and sound. 


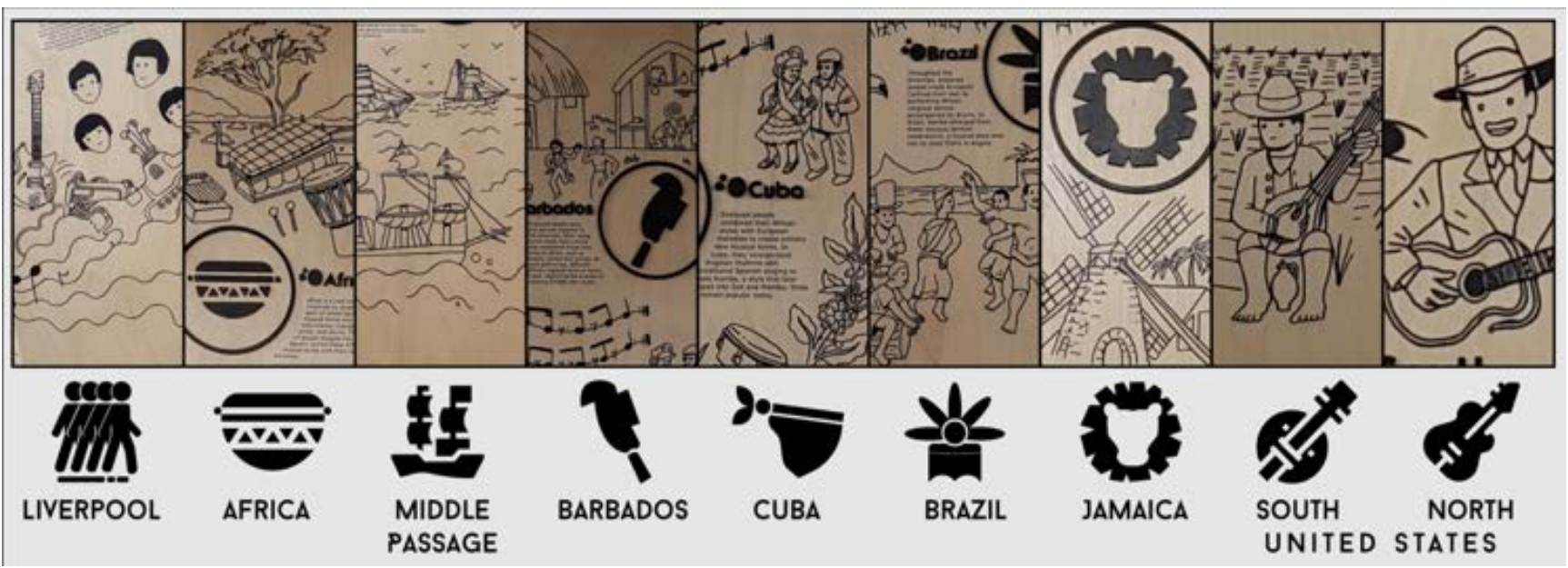

Figure 3: Afrobits Interaction Points

We used data from a diverse Cultural Heritage archives and repositories such as Europeana, the British Library, SophiA National Library (Brazil), the Library of Congress (USA), as well as some recent sound samples from artists such as Bob Marley and the Beatles. Figure 3 shows all these interactive points and some of their visual elements, which were also rendered from historic archives.

\subsection{Interactive points}

This section introduces each of the interactive points, including the background of the specific soundtracks.

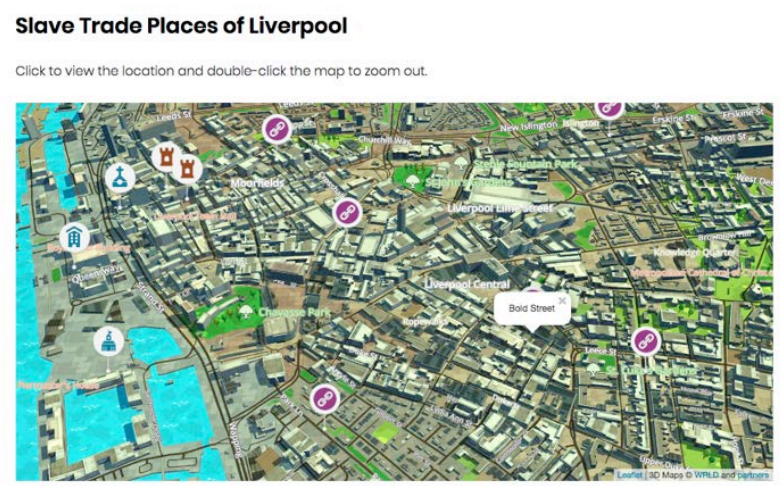

Figure 4: Afrobits Web Map. Slave-Trade Places of Liverpool

\section{Liverpool}

Iconography: The Beatles

Illustration: The Beatles, Rock ' $n$ ' Roll and electric guitar

Soundtrack: Penny Lane (Lennon \& McCartney 1966)

For Liverpool, we used The Beatles' 'Penny Lane', a song about one of Liverpool's Streets that highlights the invisible stories around Liverpool's slave trade heritage. Slavery is deeply embedded into the urban landscape of Liverpool. Numerous streets are named after slave traders, and many of the city's most impressive houses and public institutions were erected by slaving merchants. Penny Lane has commonly been associated to James Penny, a very proficient slave trader (Sadler 2018), thus connecting this street to the slave trade. Related to this, we produced an online interactive map showcasing some of the places associated to the slave trade in Liverpool (see Figure 4).

\section{Africa}

I conography: Traditional Drum Illustration: African Instruments, BaKongo masks and Takada Rhythms

Soundtrack: Musical bow lecture examples 1979: Tsongo/ Angola bows (Rycroft 1979)

A wide variety of African sounds are based on rhythm in opposition to European and Western music, which is commonly based on melody. Such rhythms are frequently accompanied by percussion instruments such as drums, bows, and lukembes. In many cases, such instruments (e.g. drums) hold deep cultural meanings across the diverse African societies. Afro-Latin music, such as Cuban Rumba and Brazilian Samba, share this African heritage through its focus on rhythm.

\section{Middle Passage}

I conography: British Slave Ship

Illustration: British Slave Ships [ Windward, Alecto and Zeldina] (Smith sc. 1834, Jackson 1780)

Soundtrack: Ee wan wabina ikuk and Lukembe tuning (Rowell 1966)

The Middle Passage was the name given by Europeans to the several month voyage from Africa to the Americas. Enslaved people sang together despite the inhumane conditions on board the slave ships, which often resulted in the forge of interpersonal powerful bonds. The illustrations showcase many of these ships, particularly those from Britain. The soundtrack used is called 'Ee wan wabina ikuk', from the Peter Cooke Uganda Recordings Collection at the British Library. The song says: "Girls are like birds in the river. Uganda 
has her freedom. I'm thinking of my girl. Oh, the eyes of women." Despite that the record indicates that the song was recorded in Alarek, Labwor, northeast Uganda, the performer noted that they were from Achioli, Uganda. It is a song about migration and freedom, which we thought suited the Middle Passage.

\section{Barbados}

Iconography: Sugar Cane Knife

Illustration: Plantation Scene and Slave Houses, Barbados (Slavery Images 1807)

Soundtrack: Yu Wele (British Library 1992)

The Barbados interactive point highlights the important link between sugar and American slavery. The demand for sugar in Europe drove the expansion of sugar cultivation in the Americas. As a result, two-thirds of the 12.5 million people enslaved through the slave trade were dragged to sugar colonies and plantations. The song, ' $Y u$ Wele', held at the British Library, sounds very similar to Merengue, a style of tropical music from the Caribbean, thus stressing its African heritage. We further exemplify such heritage through the illustration of syncopation that has become the foundation of most Latin music, and thus, popular music around the world.

\section{Cuba}

Iconography: Bandana

Illustration: Rumba Dancers (Abeba 2016)

Soundtrack: Candela (Oramas 1997)

Cuba is depicted by a bandana. Bandanas are commonly used when dancing Rumba, a heavy percussion-based music style, adopted from the various musical cultures brought to the island by African slaves. Nowadays, bandanas can have diverse meanings and are also associated with a wide range of revolutionary movements. The soundtrack of this point is 'Candela' performed by Buena Vista Social Club, who has become the representative of Cuban music of the $21^{\text {st }}$ century.

\section{Brazil}

Iconography: Carnaval Hair Dress

Illustration: Fandango Scene (Earle 1822)

Soundtrack: "Seu" doutor (Souto 1929)

The graphics for Brazil's interaction point focuses on that country's landscape and native peoples. Over five million Africans were dragged to Brazil through the slave trade, making it the largest single disembarkation point of enslaved people in the Americas. The soundtrack for this interaction point is a carnival march, showcasing the links between one of Brazil's most famous cultural extravaganzas and the slave trade. Carnival march music such as Samba, Frevo and Axé have deep roots in Angolan music, which was brought to the colony by African slaves. When African music was merged with Portuguese, Spanish, and native traditions it created a unique, warm and innovative form of music.

\section{Jamaica \\ Iconography: Lion Head \\ Illustration: Toucan \\ Soundtrack: War (Cole 1976)}

Jamaica was a colony of the British Empire for much of its modern history and was the largest slave importer and sugar exporter in the British Caribbean (Klein 1978, p.25). The soundtrack used for Jamaica is 'War', performed by Bob Marley. This song is a partial transcription of the speech given by the Ethiopian Emperor Haile Salassie when he addressed the United Nations in 1963. On it, he asks not to absolve the Western powers from responsibility for the oppression of his people (Ethiopia) and all African countries. Salassie highlighted the role of the countries' greed as the base for all racial discrimination and colonialism. Reggae music, of which Marley is perhaps the most famous artist, has been a vehicle for social commentary and religious expression. Ska and Reggae had their roots in Mento, a form of music developed by enslaved people who fused African beats and British folk tunes.

\section{South United States}

I conography: Banjo

Illustration: Traditional banjo

Soundtrack: Alabama Red (Wesley 1941)

Similar to Reggae, enslaved people in the USA melded African sounds with European melodies. The soundtrack in this point is a Murder Ballad called 'Alabama Red'. Murder Ballads are a form of musical stories that warned the audience about crimes that ended up in convictions or executions. Murder Ballads date back to the Renaissance and Baroque periods. This music genre, as well as the banjo, is not only present in Blues, but also in Rock and Roll and Country music.

\section{North United States}

Iconography: Electric Guitar Illustration: Robert J ohnson

Soundtrack: Roll Over Beethoven (Berry 1956)

This interaction point illustrates the migration of former slaves and their descendants from the south of the USA to the north. It focuses on the development of new musical forms by AfricanAmericans, who gave birth to Rock and Roll, and Jazz among many other genres. Rock and Roll embedded many of the Jazz elements such as improvisation, syncopated rhythms and bending notes to produce a very unique sound. 


\section{IMPLEMENTATION}

Recent literature has advocated for the use of physical tools when engaging with digital content (Mayes \& de Freitas 2004; Bakker et al. 2012), especially in the Cultural Heritage sector (Pereda 2019; Pereda et al. 2017; Pereda 2017). Physical tools can also help with the engagement of users with low level of digital literacy (Sylla et al. 2012). Nevertheless, the production of interactive systems often require advanced skills and knowledge, and they can be difficult to re-distribute. Materials such as paper and everyday electronics have been proven to ease and democratise the production of interactive systems (Pereda 2019; Pereda 2012; Costanza \& Huang 2009). In addition, interactive materials such as conductive pigments and electronic prototyping platforms, can offer an inexpensive source of interactivity.

For Afrobits we used a carbon-based conductive ink from Bare Conductive (Innovate UK 2016), which can be used to detect users' touch and proximity, triggering a response in a microcontroller (e.g. Arduino) or a computer. We carried out a series of workshops with Liverpool Museums, local Liverpool artists and students, where we explored how artists and general audiences including children, could create such interactive tools. We noted that conductive inks were a very flexible way of producing interactive points (Fray and Pereda 2019; Pereda et al. 2018). We found throughout our workshops that despite such flexibility, users would still have to get involved to some degree with the programming of such interactions. However, this can be done using Scratch based programming, where programs are built with more ease using assembling blocks instead of formal coding (MIT Media Lab 2019).

\subsection{A way forward}

Researchers at universities can play an essential role in providing the interdisciplinary skills to reduce gaps in the production, research and implementation of interactive storytelling systems, particularly in collaboration with the Cultural Heritage sector. Afrobits emerged from an interdisciplinary team based in disciplines within Art and Design, and Digital Humanities. This enabled inputs from Human Computer Interaction, Museum Studies, Product Design, and History among others. Heritage organisations cannot be expected to host that wide range of expertise, nor to have the necessary equipment. Heritage organisations also have limited budgets, but they can benefit from the non-monetary values that universities can provide. In this sense, students, lecturers and researchers offer values from research, storytelling, production, programming and artistic explorations, that commonly fall outside the scope of in-house skills within the heritage sector.

\section{CONCLUSION}

Afrobits presents invisible stories commonly hidden behind the geographic epistemology of Western cultures. This installation allows tangible interaction with intangible Cultural Heritage. We focused on the biopolitical inclusion of the Global South, and particularly on the Trans-Atlantic slave trade's role in shaping the culture of the Americas. We also aimed to extend the narrative beyond Anglo-based research. Our project demonstrates that universities can play an essential role in providing Heritage organisations with alternative lines of storytelling, decolonial research and development of complex technologic systems. Furthermore, interdisciplinarity and multiculturalism can help to expand inclusiveness through research and engagement.

\section{REFERENCES}

Abeba, A. (2016) Declaran patrimonio a la rumba cubana [Online]. Available:

https://elpotosi.net/cultura/20161201 declaranpatrimonio-a-la-rumba-cubana.html [Accessed October 12 2019].

Berry, C. (1956) Roll Over Beethoven. Chuck Berry is on Top.

British Library (1992) Yu wele. Syliphone record label recordings from Guinea. British Library.

Cole, A. (1976) War. Rastaman Vibration.

Costanza, E. and Huang, J. (2009) Designable

Visual Markers. Chi2009: Proceedings of the 27th

Annual Chi Conference on Human Factors in Computing Systems, Vols 1-4, 1879-1888.

Earle, A. (1822) Negro fandango scene, Campo St. Anna, Rio de Janeiro. [Watercolour - online]. Available at: National Library of Australia: https://catalogue.nla.gov.au/Record/798007 [August 8 2019].

Eltis, D. (2018) A Brief Overview of the TransAtlantic Slave Trade,' Voyages: The Trans-Atlantic Slave Trade Database [Online]. Available: https://www.slavevoyages.org/voyage/database\#ta bles [Accessed December 13 2019].

Ennals, R. (2007) From slavery to citizenship, John Wiley \& Sons.

Fleming, D. (2005) Liverpool: European Capital of... the Transatlantic Slave Trade [Online]. Amsterdam. Available:

https://www.liverpoolmuseums.org.uk/ism/resource s/amsterdam conference.aspx [Accessed December 15 2019]. 
Fray, H. and Pereda, J. (2019) Conductive Circuits. Printmaking Today.

Giblin, J., Ramos, I. and Grout, N. (2019)

Dismantling the Master's House. Third Text, 33, 471-486.

Gilroy, P. (2005) Postcolonial melancholia, Columbia University Press.

Innovate UK (2016) Bare Conductive: original paint technology opens a digital world [Online]. Available: https://www.gov.uk/government/case-studies/bareconductive-original-paint-technology-opens-adigital-world [Accessed November 29 2018].

Jackson, W. (1780) A Liverpool Slave Ship. [Oil on canvas - online]. Available at: Liverpool Museums: https://www.liverpoolmuseums.org.uk/ism/visit/floor -plan/middle-passage/slave-ship.aspx [September 10 2019].

Klein, H. S. (1978) The English Slave Trade to Jamaica, 1782-18081. The Economic History Review, 31, 25-45.

Leffler, P. K. (2006) Maritime museums and transatlantic slavery: A study in British and American identity. Journal of Transatlantic Studies, 4, 55-80.

Lennon, J. and Mccartney, P. (1966) Penny Lane. Strawberry Fields Forever. London: EMI.

Mignolo, W. D. (2002) Colonialidad Global, Capitalismo y Hegemonía Epistémica. In: Walsh, C., Schiwy, F. and Castro-Gómez, S. (eds.) Indisciplinar las ciencias sociales: Geopolíticas del conocimiento y colonialidad del poder.

Perspectivas desde lo andino. Universidad Andina Simon Bolivar.

Mit Media Lab. (2019) Scratch [Online]. Available: https://scratch.mit.edul [Accessed March 1 2019].

Oramas, F. (1997) Candela. Buena Vista Social Club. Havana, Cuba: EGREM.

Pereda, J. (2012) Web Based Tangible User Interfaces to Increase Engagement with Online Museums. MSc Web Science, University of Southampton.

Pereda, J. (2017) Exploración del Patrimonio Cultural a través de Interfaces Tangibles en la Red. Arqueología Computacional. Nuevos enfoques para el análisis y la difusión del patrimonio cultural.: INAH.

Pereda, J. (2019) A TUI To Explore Cultural Heritage Repositories on The Web. Proceedings of the Thirteenth International Conference on Tangible, Embedded, and Embodied Interaction. ACM.

Pereda, J., Fray, H. and Morris, N. (2018) Printeractive. Printeractive Workshops [Online]. Liverpool. Available: https://www.printeractive.trinkermedia.com/2018/12 104/printeractive-workshop/ [Accessed January 13 2020].
Pereda, J., Murrieta-Flores, P., Ritsos, P. D. and Roberts, J. C. (2017) Tangible User Interfaces as a Pathway for Information Visualisation for Low Digital Literacy in the Digital Humanities. IEEE VIS 2017 - 2nd Workshop on Visualization for the Digital Humanities. Phoenix, Arizona: IEEE.

Restrepo, E. and Rojas, A. (2016) Conflicto e (in) visibilidad: Retos en los estudios de la gente negra en Colombia, Organización Internacional para las Migraciones (OIM-Misión Colombia).

Rowell, H. (1966) Ee wan wabina ikuk and Lukembe tuning. Peter Cooke Uganda Collection. British Library.

Rycroft, D. (1979) Musical bow lecture examples 1979: Tsongo/ Angola bows. David Rycroft South Africa Collection. British Library.

Sadler, N. (2018) The Legacy of Slavery in Britain, Amberley Publishing.

Sanderson, F. (1972) Liverpool and the slave trade: a guide to sources. Transactions of the Historic Society of Lancashire and Cheshire, 124, 154-176.

Slavery Images. (1807) Plantation Scene and Slave Houses, Barbados, 1807-08. [Engraving online]. Available at: Slavery Images: A Visual Record of the African Slave Trade and Slave Life in the Early African Diaspora.

http://www.slaveryimages.org/s/slaveryimages/item I1472 [July 8 2019].

Smith Sc. (1834) Slave ships on the ocean. Wood engraving by Smyth. [Wood Engravings - online]. Available at: Wellcome Collection: https://wellcomecollection.org/works/sebfmc2m [September 12 2019].

Souto, E. (1929) "Seu" doutor. [Analogue sound online]. Available at: Biblioteca Nacional (Brasil): http://acervo.bndigital.bn.br/sophia/index.asp?codig o sophia=13081 [September 20 2019].

Sylla, C., Branco, P., Coutinho, C. and Coquet, E. (2012) TUls vs. GUls: comparing the learning potential with preschoolers. Personal and Ubiquitous Computing, 16, 421-432.

Wesley, J. (1941) Alabama Red. [Field Recording online]. Available at: Library of Congress: https://www.loc.gov/item/ftvbib000016/.

Wintle, C. (2013) Colonial collecting and display: encounters with material culture from the Andaman and Nicobar islands, Berghahn Books.

Zeuske, M. (2012) Historiography and research problems of slavery and the slave trade in a globalhistorical perspective. International Review of Social History, 57, 87-111. 